\title{
Half-Sandwich Rhodium and Iridium Fragments and Carboxylate Ligands as Building Blocks for the Formation of Metallamacrocycles
}

\author{
Lin Lina, Qi-Jia Fan ${ }^{\text {a }}$, Guo-Xin Jin ${ }^{\text {a* }}$
}

\begin{abstract}
A series of half-sandwich rhodium and iridium complexes containing carboxylate ligands were synthesized and characterized. Reactions between $\left[\mathrm{Cp} * \mathrm{MCl}_{2}\right]_{2}(\mathrm{M}=\mathrm{Ir}$ or $\mathrm{Rh})$ and 1,3,6bis(2-pyridyl)-1,2,4,5-tetrazine (L1) gave binuclear complexes 1 and $\mathbf{2}$ under different conditions. The half-sandwich iridium and rhodium metallamacrocycles complexes 3-5 were constructed in a stepwise manner by the addition of carboxylate ligands (sodium acetate or the conjugate bases of pyrazine-2,3-dicarboxylic acid or 3-(2-pyridyl)acrylic acid) to the solution of the binuclear precursors prepared from the reactions of $\left[\mathrm{Cp} * \mathrm{MCl}_{2}\right]_{2}(\mathrm{M}=\mathrm{Rh}$ or $\mathrm{Ir})$ with linear $\mathrm{N}, \mathrm{N}^{\prime}$-donor ligands $\left(4,4^{\prime}-\right.$ bipyridine or trans-1,2-bis(4-pyridyl)ethylene), respectively. The structures of binuclear complexes and tetranuclear macrocycles were confirmed by elemental analysis, IR, ${ }^{1} \mathrm{H}$ NMR spectroscopy and single-crystal X-ray diffraction.
\end{abstract}

Keywords: macrocycles $\bullet$ half-sandwich metal complexes $\bullet$ rhodium complexes $\bullet$ iridium complexes 


\section{Introduction}

Over the past two decades, coordination-driven self-assembly has been used as an efficient way to construct a wide range of supramolecular metallacycles. [1-5] One of the principal objectives of supramolecular chemistry is to create nanoscale structures by exerting control over the ligand sizes and shapes, and to be able to utilize the unique properties of the assemblies. [6] A small change in the ligand can produce a major effect on the self-assembled structure. Therefore, controlling or tuning the structure, which provides an understanding of self-assembly processes and the properties of the supramolecular species, is still a challenging goal. [7-9] As recent research has revealed, self-assembled

macrocycles which contain $\mathrm{Cp}^{*} \mathrm{M}(\mathrm{M}=\mathrm{Ir}, \mathrm{Rh})$ or ( $p$-cymene) Ru groups can be controlled by choosing appropriate bridging N-heterocyclic linkers and carboxylate ligands. [10, 11] The groups of Stang [12, 13], Davies [14], and others [15, 16] have pioneered the use of "chelating and bridging ligands" towards self-assembly. Ligands with two pairs of chelating sites linking two metal atoms, including $\mathrm{N}^{\wedge} \mathrm{N}-\mathrm{N}^{\wedge} \mathrm{N}$, $\mathrm{O}^{\wedge} \mathrm{O}-\mathrm{O}^{\wedge} \mathrm{O}$, and $\mathrm{O}^{\wedge} \mathrm{N}-\mathrm{O}^{\wedge} \mathrm{N}$ were investigated. [17-20] An enormous range of structures are available by using different metals and coordinating sites, many of which potentially have useful properties, such as electrochemical activity, host-guest chemistry, redox activity, magnetic behavior, etc. [21-24]

In this work, binuclear half-sandwich complexes based on $\mathrm{Cp} * \mathrm{Ir} / \mathrm{Cp} * \mathrm{Rh}$ units have been used as building blocks. These half-sandwich units have advantages in solubility, thermal stability and flexibility in fine-tuning processes, and therefore are suitable candidates for metallosupramolecular assembly. [25-26] Due to these advantages, a series of bi- and tetranuclear rhodium and iridium complexes (1-5) were synthesized and characterized.

Herein we also describe a ring opening reaction of L1, shown in Scheme 1. This result supports a similar reaction reported by $\mathrm{Bu}$ et al. [27] who used copper(II) complexes with $\mathbf{L 1}$ to arrive at a tetranuclear complex with a $\mathrm{N}^{\wedge} \mathrm{N}-\mathrm{N}^{\wedge} \mathrm{N}$ coordination motif. The synthesis of compound $\mathbf{L} \mathbf{2}$ is analogous to that observed by the group of $\mathrm{Bu}$ - the carbon center activated by coordination of the imino nitrogen 
is very susceptible to nucleophilic attack by $\mathrm{H}_{2} \mathrm{O}$ and/or adventitious amounts of $\mathrm{H}_{2} \mathrm{O}$ present in the solvent. The heterocyclic compound $\mathbf{L} 1$ reacts with $\mathrm{H}_{2} \mathrm{O}$, promoting the transformation to L2. [28]

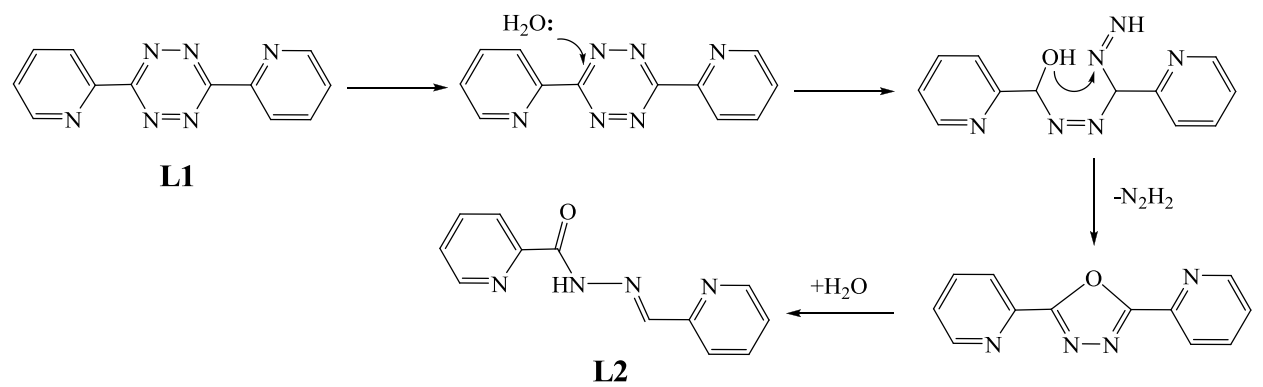

Scheme 1 Mechanism for the hydrolysis of $\mathbf{L 1}$ and the formation of $\mathbf{L 2}$.

\section{RESULTS AND DISCUSSION}

\subsection{Binuclear cyclometalated complexes 1 and 2}

As shown in Scheme 2, $\mathbf{L} \mathbf{1}$ was treated with $\left[\mathrm{Cp}^{*} \mathrm{IrCl}_{2}\right]_{2}$ in a ratio of 1:1 in $\mathrm{MeOH}$ at room temperature in the presence of AgOTf to afford the binuclear complex 1. These considerations led us to investigate the possibility of obtaining a half-sandwich rhodium complex with the same ligand. $\mathbf{L} \mathbf{1}$ was treated with $\left[\mathrm{Cp}^{*} \mathrm{RhCl}_{2}\right]_{2}$ in a ratio of 1:1 in the presence of THF containing a small amount of water. At this point, AgOTf was added and the mixture was stirred in the dark for $12 \mathrm{~h}$ to afford the binuclear rhodium complex 2 by a ring-opening reaction.
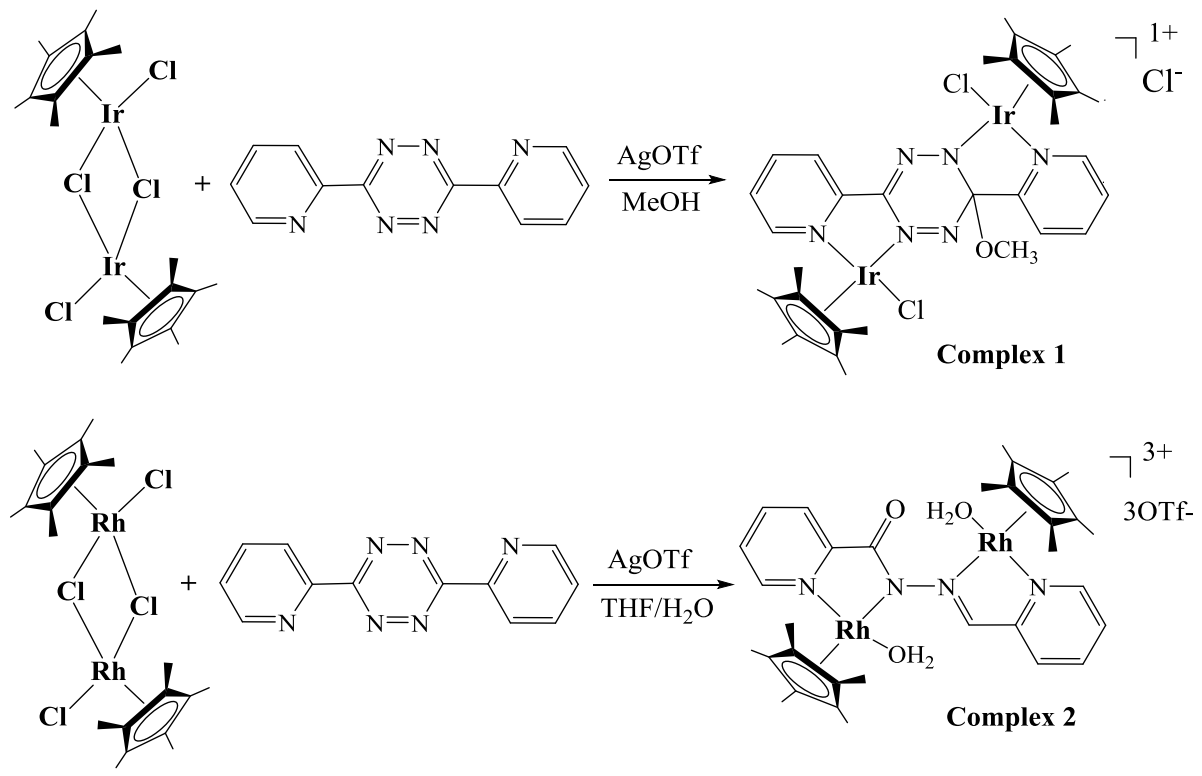

Scheme 2 Formation of complexes 1 and 2. 
Figure 1 shows the molecular structures of $\mathbf{1}$ and $\mathbf{2}$ and their cyclic voltammograms. Both complexes are binuclear, with one available coordination sites at each metal center, with each metal coordinated by two $\mathrm{Cp}^{*}$ units. The Ir-N bonds of complex 1 were found to range from 2.069 to $2.104 \AA$ (Figure 1a), while the Rh-N bond lengths of complex 2 are 2.094 and $2.167 \AA$ (Figure 1b). The M-M distances are 6.410 (complex 1) and $5.214 \AA$ (complex 2). In Figure 1b, the non-coordinated carbonyl oxygen atoms exhibit typical double bond distances of $1.260 \AA$. Long Rh1-N2 (2.167 $)$ ) and Rh2-N3 bonds ( $2.125 \AA)$ were found in the five-membered chelate rings.

Cyclic voltammetry of the binuclear complexes was carried out in a $\mathrm{CH}_{2} \mathrm{Cl}_{2} / 0.1 \mathrm{M} \mathrm{Bu}_{4} \mathrm{NPF}_{6}$ solution. Oxidation processes are observed for complexes $\mathbf{1}$ and $\mathbf{2}$, with the first oxidation step in both complexes (at 0.53 and $0.50 \mathrm{~V}$, respectively) is reversible. The second oxidation step of complex 2 is electrochemically irreversible, as can be seen from the current maxima of the forward and the reverse peaks for this step (Figure 1c, d).

a)

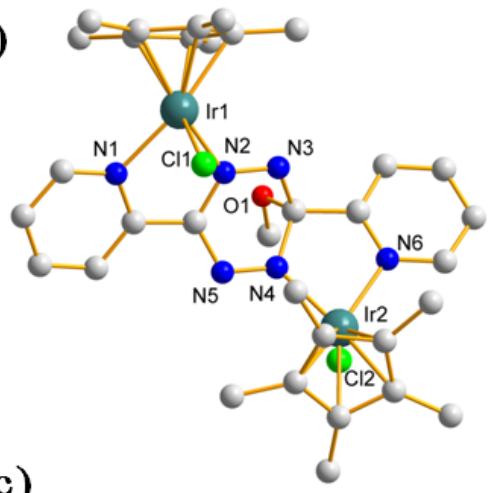

c)

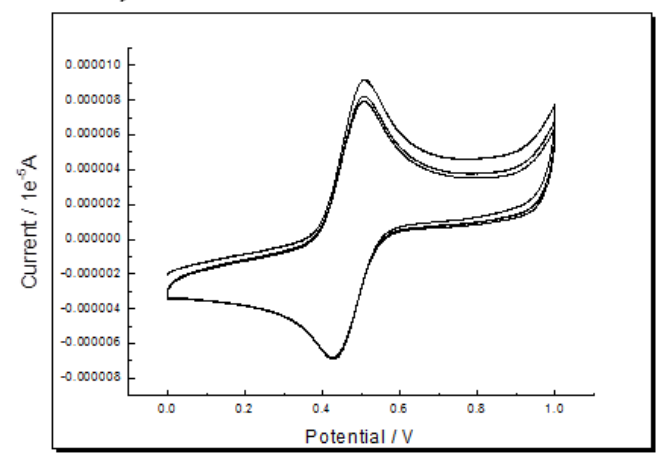

b)
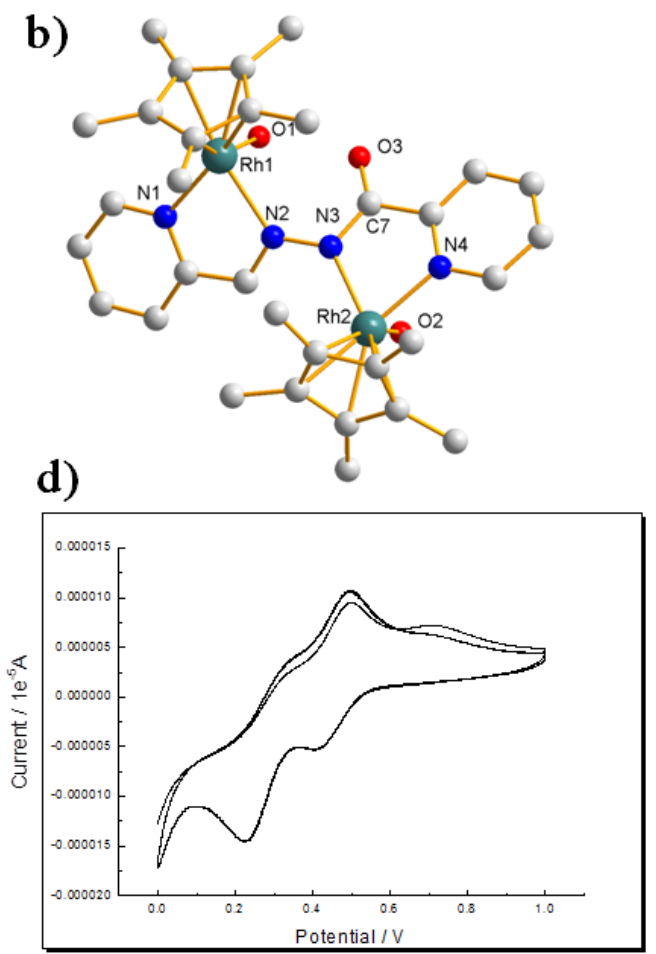

Figure 1 a) and c) Molecular structure and cyclic voltammogram of complex 1; b) and d) Molecular structure and cyclic voltammogram of complex 2 (gray for $\mathrm{C}$, blue for $\mathrm{N}$, red for $\mathrm{O}$, dark green for $\mathrm{Rh}$ or $\mathrm{Ir}$, green for $\mathrm{Cl}$, all hydrogen atoms were omitted for clarity). 


\subsection{Synthesis and characterization of complexes 3 and 4}

The synthesis of complexes 3 and $\mathbf{4}$ is depicted in Scheme 3. $\left[\mathrm{Cp}^{*} \mathrm{RhCl}_{2}\right]_{2}$ was treated with trans1,2-bis(4-pyridyl)ethylene (bpe) in a 1:1 molar ratio at room temperature, followed by four equivalents of AgOTf at room temperature overnight in the presence of $\mathrm{NaOAc}$, providing 3. Complex 4 was obtained in high yield by treating binuclear 4,4'-bipyridine(bpy)-bridged rhodium complexes with pyrazine-2,3-dicarboxylic acid in a 1:1 molar ratio at room temperature. The crystallographic data of complexes $\mathbf{3}$ and $\mathbf{4}$ are summarized in Table 1.
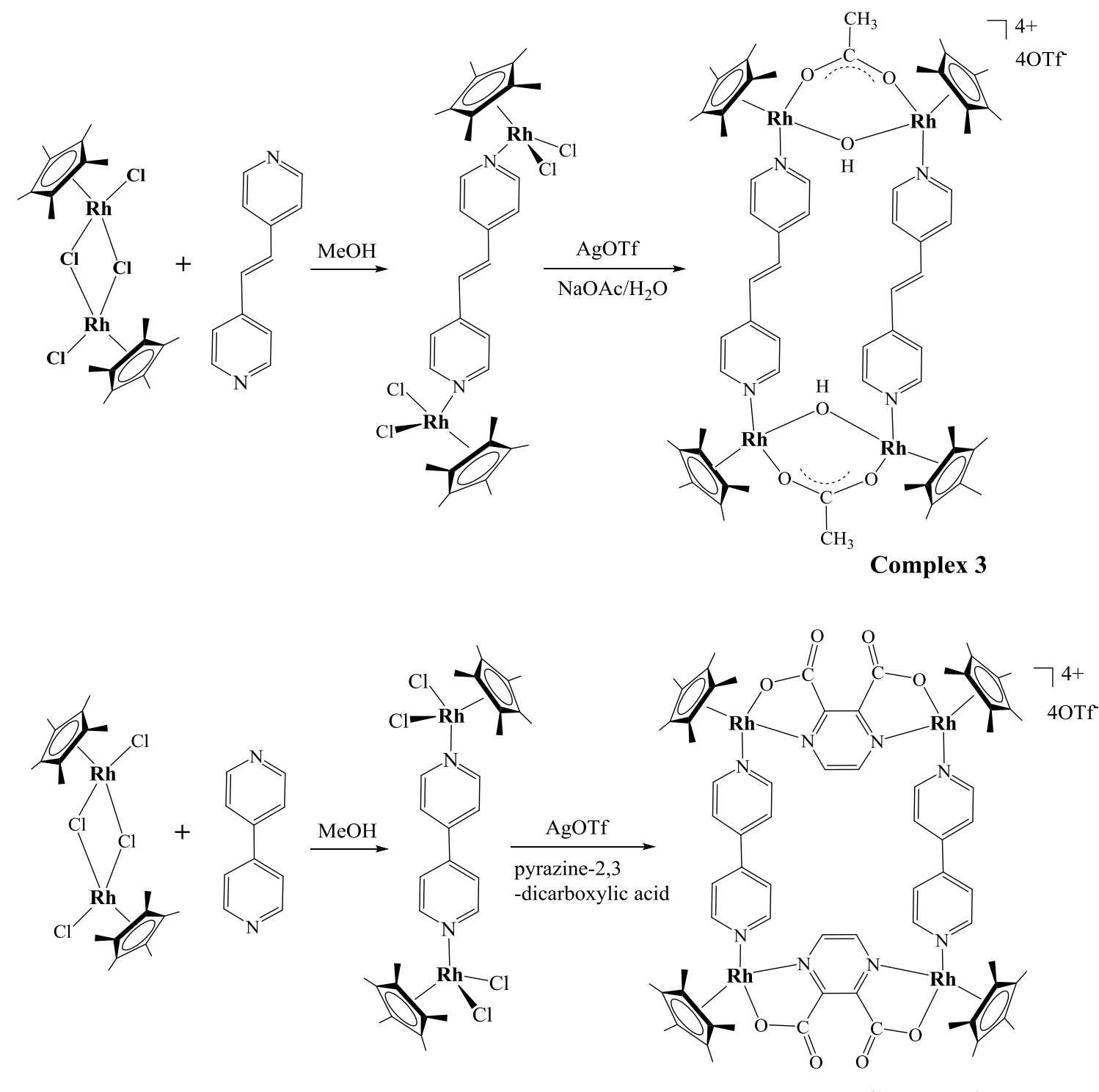

Complex 4

Scheme 3 Formation of complexes 3 and 4. 
In Figure 2a, the $\operatorname{Rh} 1 \mathrm{~A} \cdots \mathrm{Rh} 2 \mathrm{~A}$ and $\mathrm{Rh} 1 \mathrm{~A} \cdots \mathrm{Rh} 2 \mathrm{~B}$ bond lengths of $\mathbf{3}$ are 13.6149 and $3.8040 \AA$, respectively. As a consequence, the two ethylene groups are nearly parallel to each other, with a distance between the ethylene centroids of $3.7974 \AA$. The pyridyl rings were also found to be parallel to each other. In these complexes, the distances between the two pyridyl-based ligands are small because of the presence of $\pi-\pi$ interactions and fall within the range required for $[2+2]$ photoreaction. When crystals or a powdered crystalline sample of complex $\mathbf{3}$ was subjected to UV irradiation using an Hg lamp for a period of approximately $48 \mathrm{~h}$, no dimerization was observed to occur by ${ }^{1} \mathrm{H}$ NMR spectroscopy. In Figure $2 \mathrm{~b}$, the $\mathrm{Rh} 1 \cdots \mathrm{Rh} 2$ and $\mathrm{Rh} 1 \cdots \mathrm{Rh} 3$ distances are 11.2707 and $6.9357 \AA$ and these values are significantly smaller than those of $\mathbf{3}$. Complex $\mathbf{4}$ showed that each $\mathrm{Rh}$ atom was coordinated by two nitrogen atoms of the 4,4'-bipyridine and pyrazine ligands, and one carboxylate oxygen atom from the pyrazine2,3-dicarboxylate acid ligand. The N-Rh-O angle of 4 is $77.47^{\circ}$, and the Rh1A-N1B, Rh1A-N1A, Rh1A-O1A distances are 2.1236, 2.1170, $2.0695 \AA$, respectively. In conclusion, a concise method has been developed to functionalize carboxylate ligands under mild conditions, which can be used to assemble supramolecular nanochannel architectures.

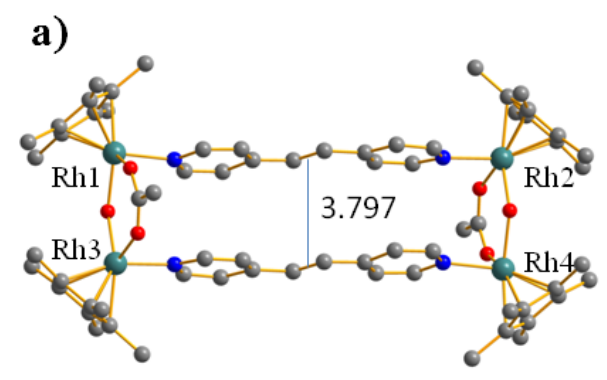

c)

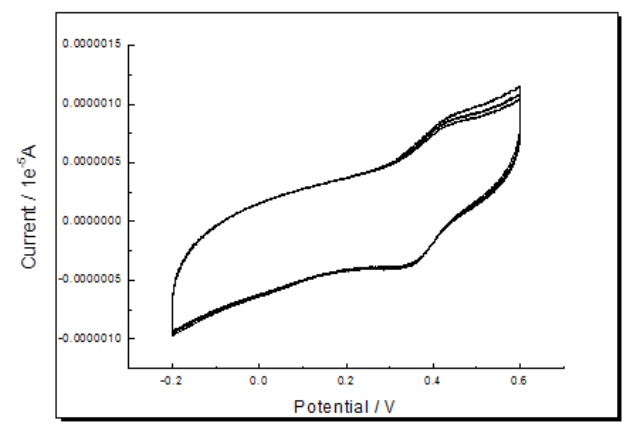

b)

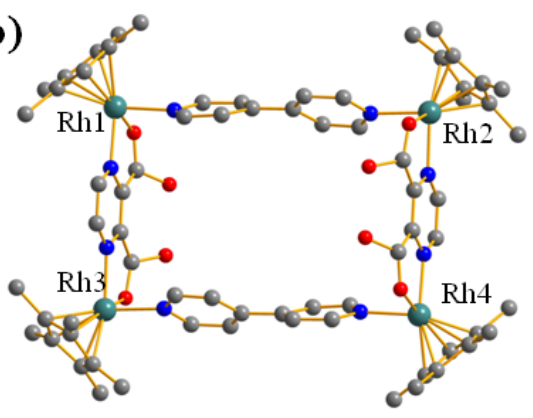

d)

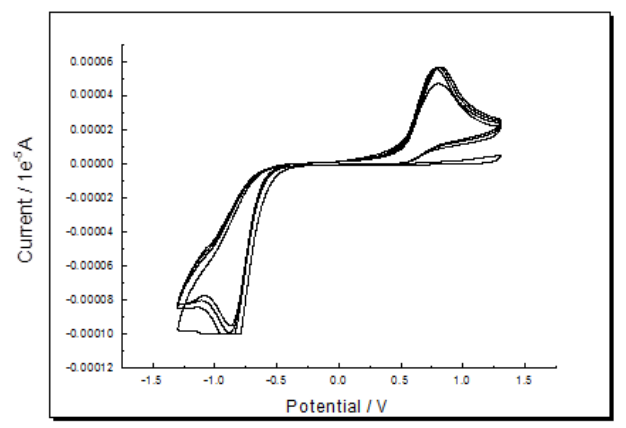


Figure 2. a) and c) Molecular structure and cyclic voltammogram of complex 3; b) and d) Molecular structure and cyclic voltammogram of complex 4 (gray for $\mathrm{C}$, blue for $\mathrm{N}$, red for $\mathrm{O}$, dark green for $\mathrm{Rh}$, green for $\mathrm{Cl}$, all hydrogen atoms were omitted for clarity).

An oxidation process was seen for 3 at around $0.43 \mathrm{~V}$ in $\mathrm{CH}_{2} \mathrm{Cl}_{2} / 0.1 \mathrm{M} \mathrm{Bu}_{4} \mathrm{NPF}_{6}$. On the reductive side, complex 3 displays a reduction step where the forward wave is seen at $0.33 \mathrm{~V}$ (Figure. 2c). In Figure $2 \mathrm{~d}$, redox waves for complex 4 were observed ranging from -0.88 to $0.81 \mathrm{~V}$.

\subsection{Synthesis and characterization of complex 5}

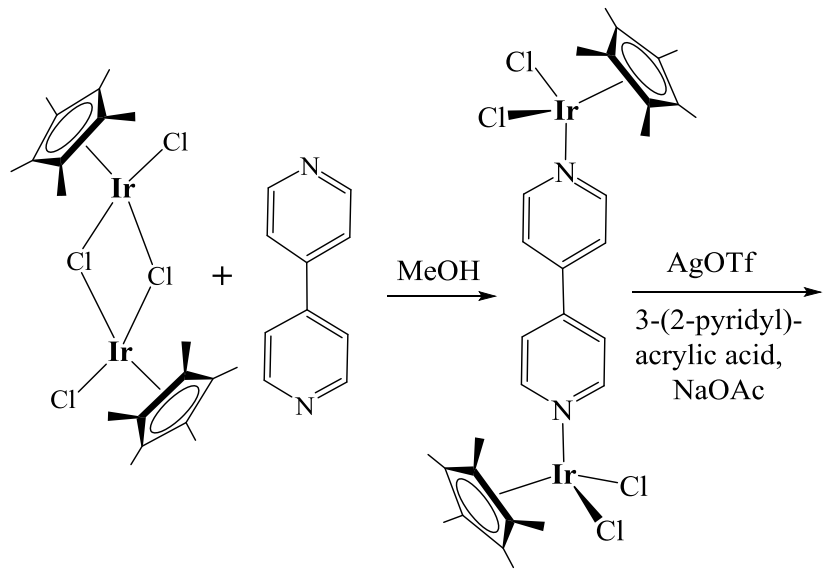

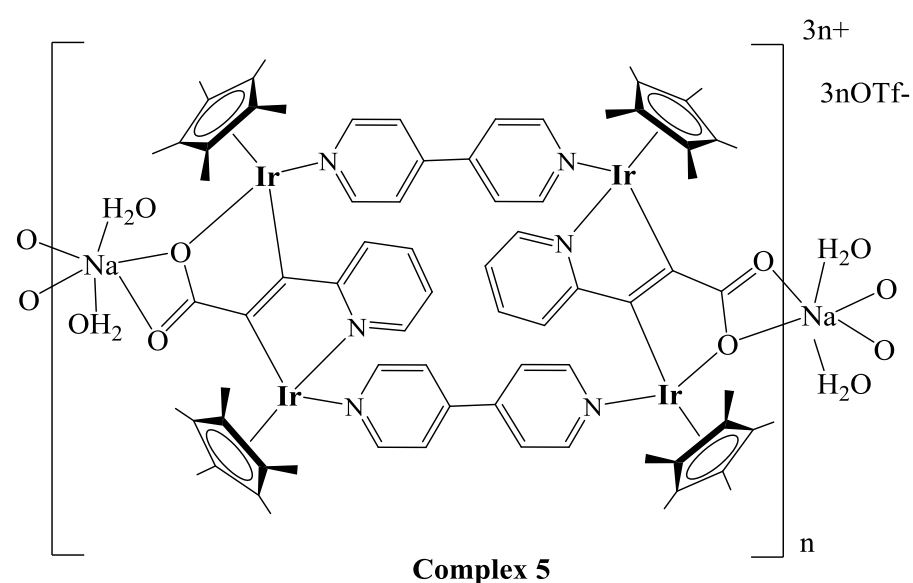

Complex 5

Scheme 4 Formation of complex 5.

Self-assembly of the zigzag complex 5 was achieved through combination of a binuclear bpybridged iridium complex and followed by four equivalents of AgOTf at room temperature overnight and two equivalents of 3-(2-pyridyl) acrylic acid, with addition of an excess of sodium acetate (Scheme 4). Complex 5 was characterized by IR, NMR, elemental analysis and single-crystal X-ray diffraction. The molecular structure of 5 (Figure 3a) shows that each 3-(2-pyridyl)acrylate ligand is bound to two iridium atoms, through double-site $\mathrm{C}$-H activation involving $\sigma$-coordination to the olefin group. The two bpy ligands are orthogonal to the planes made by the two iridium atoms and the carboxylate ligands. In fact, Ir3 is coordinated by two atoms( $\mathrm{N} 3$ and $\mathrm{O} 3$ ) of the 3-(2-pyridyl)acrylate sodium salt bridging in an asymmetric mode with two ions belonging to distinct binuclear units $(\mathrm{Ir} 3-\mathrm{N} 3=2.0810 \AA$, Ir1-O3 = $2.0994 \AA$ A).

In the zigzag structure shown in Figure 3b, the Na...Na distances are 12.8891 and $12.4049 \AA$. 
Each $\mathrm{Na}$ ion is hexacoordinate, each sodium atom is ligated by six oxygen atoms, two from each macrocycle $\left(\mathrm{Na} 1-\mathrm{O} 3=2.3419 \AA\right.$; $\mathrm{Na} 1-\mathrm{O} 4=2.4914 \AA$ ), and two from $\mathrm{H}_{2} \mathrm{O}$ molecules. This may indicate that the $\mathrm{C}-\mathrm{H}$ activation and self-assembly of the metallacycle formation is cooperative, thus giving rise to a $1 \mathrm{D}$ coordination polymer.

a)

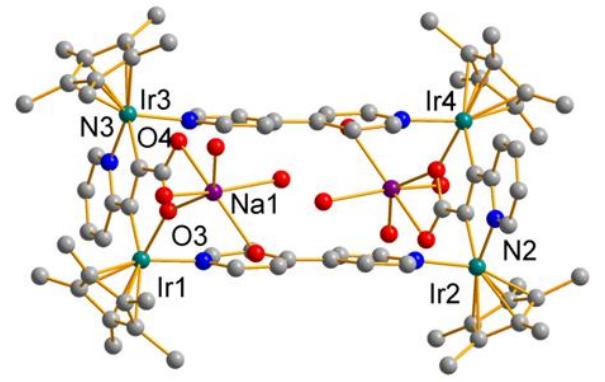

c)

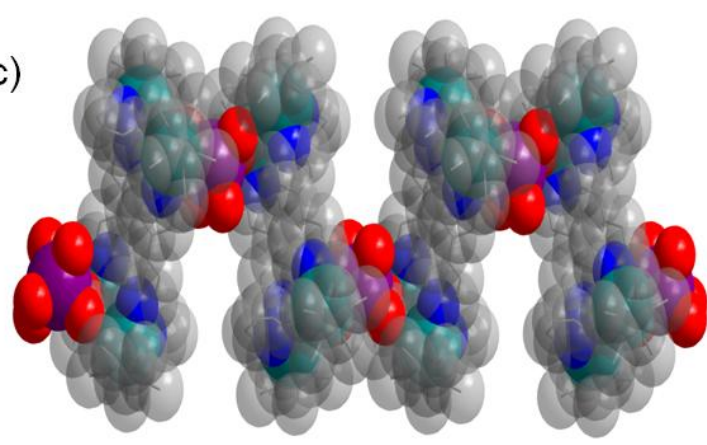

b)

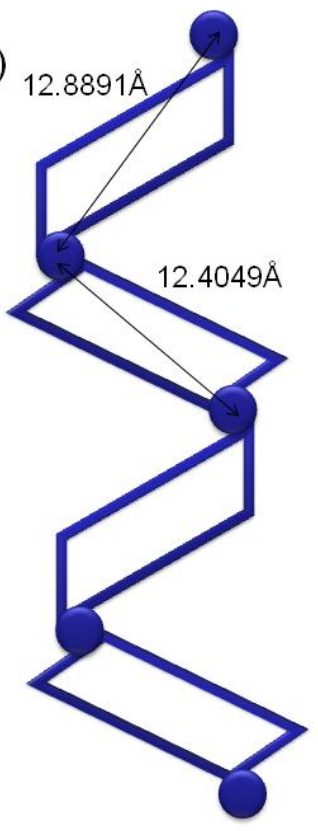

Figure 3 a) Molecular structure of complex 5; b) Schematic of the zigzag structure, with the blue circles representing $\mathrm{Na}$ ions; c) Space-filling model of the 1D macrocycles linked by metal ions (gray for C, blue for N, red for O, dark green for $\mathrm{Ir}$, green for $\mathrm{Cl}$, all hydrogen atoms were omitted for clarity).

\section{CONCLUSIONS}

In summary, we have used half-sandwich rhodium and iridium complexes with nitrogen-donor or carboxylate ligands to construct organometallic binuclear complexes and tetranuclear macrocycles. In one case, L1 underwent ring-opening under mild conditions [29]. We have shown that all of the macrocycles lead to different shapes in their self-assembled structures. These differences depend on several factors: the nature of the metal centers, the shape of the linker ligand, the donor types and so on. [30] In specific templated assemblies of metallamacrocycles, the coordination model of the metal is the main factor that determines the nuclearity and geometry of the macrocycle formed. Because of this, 
[24] Y. Ye, T. R. Cook, S.-P. Wang, J. Wu, S.-J. Li, P. J. Stang, J. Am. Chem. Soc. 137 (2015) 1189611899.

[25] Y.-Y. Zhang, X.-Y. Shen, L.-H. Weng, G.-X. Jin, J. Am. Chem. Soc. 136 (2014) 15521-15524.

[26] L. Zhang, Y.-J. Lin, Z.-H. Li, G.-X. Jin, J. Am. Chem. Soc. 137 (2015) 13670-13678.

[27] X.-H. Bu, H. Liu, M. Du, L. Zhang, Y.-M. Guo, Inorg. Chem. 41 (2002) 1855-1861.

[28] A. Dogan, B. Schwederski, T. Schleid, F. Lissner, J. Fiedler, W. Kaim, Inorg. Chem. Comm. 7 (2004) 220-223.

[29] M. V. D. Meer, S. Manck, S. Sobottka, S. Plebst, B. Sarkar, Organometallics 34 (2015) 5393-5400.

[30] G.-L. Wang, Y.-J. Lin, G,-X, Jin, Chem. Eur. J. 17 (2011) 5578-5587.

[31] C. White, A. Yates, P. M. Maitlis, Inorg. Synth. 29 (1992) 228-234.

[32] SHELXS-97: G. M. Sheldrick, Acta Crystallogr. Sect. A 64 (2008) 112-122. 
the amount of sodium acetate and the solvent used for crystallization was found to promote the formation of complex 5 .

\section{EXPERIMENTAL SECTION}

The starting materials $\left[\mathrm{Cp}^{*} \mathrm{MCl}_{2}\right]_{2}(\mathrm{M}=\mathrm{Rh}$, Ir) were prepared by literature methods [31], while other chemicals were obtained commercially and used without further purification. All manipulations were performed using standard Schlenk techniques under an atmosphere of nitrogen. However, once the reactions were completed, subsequent work-up was performed without precaution, as the compounds are air-stable. Elemental analyses were performed on an Elementar III Vario EI analyzer. IR (KBr) spectra were recorded on the Nicolet FT-IR spectrophotometer. ${ }^{1} \mathrm{H}$ NMR spectra (400 MHz) were measured on a Bruker DMX-500 spectrometer in $\mathrm{CDCl}_{3}(\delta 7.26)$ or $\mathrm{CD}_{3} \mathrm{OD}(\delta 3.31)$.

\section{Synthesis of complex 1}

A mixture of $\left[\mathrm{Cp}^{*} \mathrm{IrCl}_{2}\right]_{2}(80.0 \mathrm{mg}, 0.1 \mathrm{mmol})$, and $\mathbf{L 1}(23.6 \mathrm{mg}, 0.1 \mathrm{mmol})$ in $\mathrm{MeOH}(10 \mathrm{~mL})$ was stirred for $8 \mathrm{~h}$, then AgOTf (51.2 $\mathrm{mg}, 0.2 \mathrm{mmol})$ was added to the solution and the reaction was stirred in the dark for $12 \mathrm{~h}$. The solution was concentrated to give a dark red solid, which was washed with diethyl ether and dried under vacuum. X-ray quality crystals for complex $\mathbf{1}$ were obtained by slow diffusion of diethyl ether into methanol. Yield: $99.3 \mathrm{mg}(91 \%)$. Anal. Calcd (\%) for $\mathrm{C}_{35} \mathrm{H}_{49} \mathrm{~N}_{6} \mathrm{O}_{3} \mathrm{Cl}_{3} \mathrm{Ir}_{2}: \mathrm{C}$ 38.47, H 4.52, N 7.69. Found: C 38.84, H 4.73, N 7.88. IR (KBr disk): 3421(w), 2360(w), 1650(w), 1449(s), 1415 (s), 1267(s), 1245(w), 1178(s), 1079(w), 1018(w), 784(m), 646(w) cm ${ }^{-1} .{ }^{1} \mathrm{H}$ NMR (400 $\left.\mathrm{MHz}, \mathrm{CD}_{3} \mathrm{OD}, \mathrm{ppm}\right): \delta=8.87-8.74(\mathrm{~d}, 2 \mathrm{H}, \mathrm{Py}-\mathrm{H}), 8.44-8.30(\mathrm{~d}, 2 \mathrm{H}, \mathrm{Py}-\mathrm{H}), 8.21-8.00(\mathrm{~d}, 2 \mathrm{H}, \mathrm{Py}-\mathrm{H})$, 7.91-7.59 (d, 2H, Py -H), $1.66\left(\mathrm{~d}, 30 \mathrm{H}, \mathrm{Cp}^{*}-\mathrm{H}\right)$.

\section{Synthesis of complex 2}

A procedure analogous to the preparation of complex 1 was used: [Cp* $\left.\mathrm{RhCl}_{2}\right]_{2}(62 \mathrm{mg}, 0.1 \mathrm{mmol}), \mathbf{L 1}$ (23.6 mg, $0.1 \mathrm{mmol})$ and AgOTf $(51.2 \mathrm{mg}, 0.2 \mathrm{mmol})$ were added to THF (10 mL) and stirred for $12 \mathrm{~h}$ at 
room temperature. Slow evaporation of a THF / diethyl ether solution of complex 2 in air produced red crystals suitable for X-ray crystallography. Yield: $111.4 \mathrm{mg}$ (93\%). Anal. Calcd (\%) for $\mathrm{C}_{35} \mathrm{H}_{41} \mathrm{~N}_{4} \mathrm{O}_{13} \mathrm{~S}_{3} \mathrm{~F}_{9} \mathrm{Rh}_{2}$ : C 35. 07, $\mathrm{H}$ 3.45, N 4.67. Found: C 35.43, H 3.71, N 4.75. IR (KBr disk): 3421(w), 2345(w), 1718(w), 1607(s), 1490(s), 1382(s), 1318(w), 1264(s), 1082(w), 1026(s), 782(w), 752(m), 637(w) $\mathrm{cm}^{-1} .{ }^{1} \mathrm{H}$ NMR (400 MHz, $\left.\mathrm{CD}_{3} \mathrm{OD}, \mathrm{ppm}\right): \delta=8.87-8.29(\mathrm{~d}, 2 \mathrm{H}, \mathrm{Py}-\mathrm{H}), 8.36-8.34(\mathrm{~d}$, 2H, Py -H), 7.96-7.91 (d, 2H, Py -H), 7.53-7.49 (d, 2H, Py -H), 7.24-7.20 (d, 2H, Py -H) 1.67 (d, 30H, $\left.\mathrm{Cp}^{*}-\mathrm{H}\right)$.

\section{Synthesis of complex 3}

Bpe (18.3 mg, $0.1 \mathrm{mmol})$ was stirred with $\left[\mathrm{Cp} * \mathrm{RhCl}_{2}\right]_{2}(62 \mathrm{mg}, 0.1 \mathrm{mmol})$ in dry $\mathrm{MeOH}(10 \mathrm{~mL})$ for 4 $\mathrm{h}$ at room temperature. AgOTf $(51.2 \mathrm{mg}, 0.2 \mathrm{mmol})$ was then added to the solution and the reaction was stirred in the dark for $12 \mathrm{~h}$. Subsequently, sodium acetate $(8.2 \mathrm{mg}, 0.1 \mathrm{mmol})$ was added to the mixture, and this was vigorously stirred for $8 \mathrm{~h}$ at room temperature. Crystallization from dichloromethane / diethyl ether provided complex 3. Yield: $187.5 \mathrm{mg}$ (83\%). Anal. Calcd (\%) for $\mathrm{C}_{88} \mathrm{H}_{92} \mathrm{~N}_{4} \mathrm{O}_{18} \mathrm{~S}_{4} \mathrm{~F}_{12} \mathrm{Rh}_{4}$ : C 46.74, H 4.10, N 2.48. Found: C 46.94, H 4.48, N 2.71. IR (KBr disk): 3474(w), 3100(w), 1609(w), 1455(s), 1261(s), 1223(s), 1157(s), 1071(w), 1030(s), 821(w), 638(w), 573(m), 517(w) $\mathrm{cm}^{-1} .{ }^{1} \mathrm{H}$ NMR (400 MHz, $\left.\mathrm{CD}_{3} \mathrm{OD}, \mathrm{ppm}\right): \delta=7.53-7.51(\mathrm{~d}, 4 \mathrm{H}, \mathrm{Py}-\mathrm{H}), 7.10-7.08\left(\mathrm{~d}, 2 \mathrm{H}, \mathrm{CH}_{2}-\mathrm{H}\right), 7.08-7.01(\mathrm{~d}, 2 \mathrm{H}$, $\left.\mathrm{CH}_{2}-\mathrm{H}\right), 7.00-6.99$ (t, 4H, Py-H), 2.18-2.17 (t, 6H, $\left.\mathrm{CH}_{3}-\mathrm{H}\right), 1.61$ (s, 60H, Cp $\left.{ }^{*}-\mathrm{H}\right)$.

\section{Synthesis of complex 4}

A mixture of $\left[\mathrm{Cp}^{*} \mathrm{RhrCl}_{2}\right]_{2}(62 \mathrm{mg}, 0.1 \mathrm{mmol})$ and bpy $(16 \mathrm{mg}, 0.1 \mathrm{mmol})$ was added to $10 \mathrm{~mL}$ of $\mathrm{MeOH}$ for $8 \mathrm{~h}$. AgOTf $(51.2 \mathrm{mg}, 0.2 \mathrm{mmol})$ was then added to the solution and the reaction was stirred in the dark for $12 \mathrm{~h}$. Pyrazine-2,3-dicarboxylic acid $(18.6 \mathrm{mg}, 0.1 \mathrm{mmol})$ was then added to the solution and it was stirred for 8 h. Crystallization from dichloromethane / diethyl ether provided complex 4 . Yield: $160.5 \mathrm{mg}(84 \%)$. Anal. Calcd (\%) for $\mathrm{C}_{74} \mathrm{H}_{80} \mathrm{~F}_{6} \mathrm{~N}_{8} \mathrm{O}_{14} \mathrm{Rh}_{4} \mathrm{~S}_{2}$ : C 46.90, H 4.25, N 5.91. Found: $\mathrm{C}$ 46.53, H 4.01, N 5.65. IR (KBr disk): 3462(w), 1654(w), 1609(w), 1384(s), 1341(s), 1280(s), 1258(s), 
1123(w), 1096(s), 1031(s), 639(w), 567(m), 589(w) $\mathrm{cm}^{-1} .{ }^{1} \mathrm{H} \mathrm{NMR}\left(400 \mathrm{MHz}, \mathrm{CDCl}_{3}, \mathrm{ppm}\right): \delta=9.47-$

9.42 (d, 4H, Py-H), 8.64-8.57 (d, 8H, bpy -H), 8.98-8.06 (d, 8H, bpy -H), 1.67 (s, 60H, Cp $\left.{ }^{*}-\mathrm{H}\right)$.

\section{Synthesis of complex 5}

Bpe (18 mg, $0.1 \mathrm{mmol})$ was stirred with $\left[\mathrm{Cp}^{*} \mathrm{IrCl}_{2}\right]_{2}(62 \mathrm{mg}, 0.1 \mathrm{mmol})$ in dry dichloromethane $(15 \mathrm{~mL})$ for $8 \mathrm{~h}$ at room temperature. The solution was then worked up according to the synthetic method of complexes 3 and 4. AgOTf (51.2 $\mathrm{mg}, 0.2 \mathrm{mmol})$ was then added to the solution and the reaction was stirred in the dark for 12 h. 3-(2-pyridyl)acrylic acid (14.9 mg, $0.1 \mathrm{mmol})$ was then added into the solution and it was stirred for 8 h. Crystallization from dichloromethane / diethyl ether provided complex 5. Yield: $154.6 \mathrm{mg}(61.2 \%)$. Anal. Calcd (\%) for $\mathrm{C}_{81} \mathrm{H}_{100} \mathrm{~N}_{6} \mathrm{O}_{19} \mathrm{NaIr}_{4} \mathrm{~S}_{3} \mathrm{~F}_{9}$ : C 38.59, H 4.00, N 3.33. Found: C 38.86, H 4.21, N 3.61. IR (KBr disk): 3500(w), 3100(w), 2963(w), 1602(s), 1557(s), 1455(s), 1260(s), 1123(w), 1156(s), 1030(s), 801(w), 637(s), 572(s) $\mathrm{cm}^{-1} .{ }^{1} \mathrm{H}$ NMR $\left(400 \mathrm{MHz}, \mathrm{CD}_{3} \mathrm{OD}, \mathrm{ppm}\right): \delta=8.97-$ 8.92 (d, 2H, Py-H), 8.34-8.31 (d, 2H, Py-H), 8.17-8.12 (d, 2H, Py-H), 7.85-7.79 (t, 2H, Py-H), 7.57-7.55 (t, 18H, bpy-H), 7.46-7.37 (t, 18H, bpy-H), 1.62 (d, 60H, Cp*-H).

\section{X-ray crystal structure determination}

All determinations of unit cell data were performed with graphite-monochromated $\operatorname{Mo} K_{\alpha}$ radiation $(\lambda=$ $0.71073 \AA$ ) for complexes 1-5. Data were collected at 173(2) K using the $\omega$ scan technique. These structures were solved by direct methods, using Fourier techniques, and refined on $\mathrm{F}^{2}$ by a full-matrix leastsquares method. All calculations were carried out with the SHELXTL [32] program. Crystal data, data collection parameters, and the results of the analysis of these complexes are listed in Table 1.

The crystallographic data of complexes 1-5 are summarized in Table 1. CCDC-1447454 (1), 1447455 (2), 960939 (3), $1447456(\mathbf{4}), 960940$ (5) contain the supplementary crystallographic data for this paper. These data can be obtained free of charge from The Cambridge Crystallographic Data Centre via www. ccdc.cam.ac.uk/data_request/cif. 


\section{ACKNOWLEDGEMENTS}

This work was supported by the National Science Foundation of China (21531002, 21374019), the Program for Changjiang Scholars and Innovative Research Team in University (IRT-15R12), the National Basic Research Program of China (2015CB856600) and the Shanghai Science Technology Committee (13JC1400600). 
Table 1. Crystallographic data and structure refinement parameters for complexes 1-5

\begin{tabular}{|c|c|c|c|c|c|}
\hline & $\mathbf{1}$ & 2 & 3 & 4 & 5 \\
\hline Chemical Formula & $\mathrm{C}_{38} \mathrm{H}_{49} \mathrm{Ir}_{26} \mathrm{O}_{3}$ & $\mathrm{C}_{35} \mathrm{H}_{41} \mathrm{~N}_{4} \mathrm{O}_{13} \mathrm{Rh}_{2} \mathrm{~S}_{3} \mathrm{~F}_{9}$ & $\mathrm{C}_{94} \mathrm{H}_{94} \mathrm{~N}_{4} \mathrm{O}_{18} \mathrm{Rh}_{4} \mathrm{~S}_{4} \mathrm{~F}_{12}$ & $\mathrm{C}_{76} \mathrm{H}_{80} \mathrm{~N}_{8} \mathrm{O}_{20} \mathrm{Rh}_{4} \mathrm{~S}_{4} \mathrm{~F}_{12}$ & $\mathrm{C}_{81} \mathrm{H}_{100} \mathrm{~N}_{6} \mathrm{O}_{19} \mathrm{NaIr}_{4} \mathrm{~S}_{3} \mathrm{~F}_{9}$ \\
\hline $\mathrm{FW}$ & 1092.55 & 1202.75 & 2403.03 & 2193.36 & 4601.6 \\
\hline $\mathrm{T} /[\mathrm{K}]$ & $173(2)$ & $173(2)$ & $173(2)$ & $173(2)$ & $173(2)$ \\
\hline$\lambda / \AA$ & 0.71073 & 0.71073 & 0.71073 & 0.71073 & 0.71073 \\
\hline Crystal system & Monoclinic & Triclinic & Monoclinic & Monoclinic & Triclinic \\
\hline Space group & P 21/c & $P-1$ & $\mathrm{C} 2 / \mathrm{c}$ & $\mathrm{C} 2 / \mathrm{m}$ & $P-1$ \\
\hline $\mathrm{a} / \AA ̊$ & $13.1340(16)$ & $8.4908(7)$ & 40.798(3) & $17.808(4)$ & $15.2581(10)$ \\
\hline $\mathrm{b} / \AA$ & $14.3378(18)$ & $13.2306(12)$ & $12.7785(9)$ & $30.496(7)$ & $16.3033(11)$ \\
\hline $\mathrm{c} / \AA ̊$ & $20.753(3)$ & $21.2880(18)$ & $19.3259(14)$ & $8.5731(19)$ & $19.5833(13)$ \\
\hline$\alpha /^{\circ}$ & 90 & $83.4130(10)$ & 90 & 90 & $93.1680(10)$ \\
\hline$\beta /^{\circ}$ & $95.890(2)^{\circ}$ & $87.2760(10)$ & 105.7910(10) & $101.977(4)^{\circ}$ & $103.1230(10)$ \\
\hline$\gamma /{ }^{\circ}$ & 90 & $77.3800(10)$ & 90 & 90 & $102.6100(10)$ \\
\hline $\mathrm{V} / \AA^{3}$ & $3887.5(8)$ & 2317.7(3) & $9695.1(12)$ & $4554.4(18)$ & $4601.6(5)$ \\
\hline $\mathrm{Z}$ & 4 & 2 & 4 & 2 & 2 \\
\hline $\mathrm{F}(000)$ & 2120 & 1212 & 4840 & 2208 & 2456 \\
\hline Reflections collected & 25399 & 16289 & 33427 & 15838 & 36018 \\
\hline Completeness to $\theta$ & $99.8 \%$ & $98.4 \%$ & $99.4 \%$ & $99.1 \%$ & $98.5 \%$ \\
\hline Data/restraints/param. & 7966 / 2 / 462 & $9954 / 131 / 665$ & 10404 / 92 / 556 & $5030 / 31 / 265$ & $22563 / 89 / 1078$ \\
\hline Goodness-of-fit on $\mathrm{F}^{2}$ & 1.073 & 1.131 & 1.061 & 1.000 & 0.998 \\
\hline Final $\mathrm{R}$ indices $[\mathrm{I}>2 \sigma(\mathrm{I}) \mathrm{a}]$ & $\begin{array}{l}\mathrm{R}_{1}=0.0324 \\
\mathrm{wR}_{2}=0.0950\end{array}$ & $\begin{array}{l}\mathrm{R}_{1}=0.0497 \\
\mathrm{wR}_{2}=0.1475\end{array}$ & $\begin{array}{l}\mathrm{R}_{1}=0.0598 \\
\mathrm{wR}_{2}=0.1718\end{array}$ & $\begin{array}{l}\mathrm{R}_{1}=0.0761 \\
\mathrm{wR}_{2}=0.2113\end{array}$ & $\begin{array}{l}\mathrm{R}_{1}=0.0541 \\
\mathrm{wR}_{2}=0.1645\end{array}$ \\
\hline $\begin{array}{l}\text { Largest diff. peak/ hole } \\
\left(\mathrm{e} \AA^{-3}\right)\end{array}$ & $1.915 /-1.875$ & $2.177 /-1.014$ & $1.582 /-1.205$ & $1.857 /-1.012$ & $5.598 /-2.097$ \\
\hline
\end{tabular}

${ }^{\mathrm{a}} R_{1}=\Sigma\left\|F_{0}|-| F_{\mathrm{c}}\right\|\left(\right.$ based on reflections with $\left.\mathrm{F}_{0}{ }^{2}>2 \sigma \mathrm{F}^{2}\right) . w R_{2}=\left[\Sigma\left[w\left(F_{0}{ }^{2}-F_{\mathrm{c}}{ }^{2}\right)^{2}\right] / \Sigma\left[w\left(F_{0}^{2}\right)^{2}\right]\right]^{1 / 2} ; \mathrm{w}=1 /\left[\sigma^{2}\left(F_{0}{ }^{2}\right)+(0.095 P)^{2}\right] ; P=\left[\max \left(F_{0}{ }^{2}, 0\right)+2 F_{\mathrm{c}}{ }^{2}\right] / 3\left(\right.$ also with $\left.F_{0}{ }^{2}>2 \sigma F^{2}\right)$ 


\section{REFERENCES}

[1] R. Chakrabarty, P. S. Mukherjee, P. J. Stang, Chem. Rev. 111 (2011) 6810-6918.

[2] H. Amouri, C. Desmarets, J. Moussa, Chem. Rev. 112 (2012) 2015-2041.

[3] M. Yoshizawa, J. K. Klosterman, M. Fujita, Angew. Chem., Int. Ed. 48 (2009) 3418-3438.

[4] S. M. Biros, R. M. Yeh, K. N. Raymond, Angew. Chem., Int. Ed. 47 (2008) 6062-6064.

[5] N. P. Power, S. J. Dalgarno, J. L. Atwood, Angew. Chem., Int. Ed. (2007) 46 8601-8604.

[6] A. K. Bar, R. Chakrabarty, P. S. Mukherjee, Organometallics 27 (2008) 3806-3810.

[7] R. P. John, K. Lee, B. J. Kim, B. J. Suh, H. Rhee, M. S. Lah, Inorg. Chem. 44 (2005) 7109-7121.

[8] S. Mukhopadhyay, W. H. Armstrong, J. Am. Chem. Soc. 125 (2003), 13010-13011

[9] Z. Lu, C. B. Knobler, H. Furukawa, B. Wang, G. Liu, O. M. Yaghi, J. Am. Chem. Soc. 131 (2009) 12532-12533.

[10] B. Therrien, G. Süss-Fink, P. Govindaswamy, A. K. Renfrew, P. J. Dyson, Angew. Chem., Int. Ed. 47 (2008) 3773-3776.

[11] W. Meng, B. Breiner, K. Rissanen, J. D. Thoburn, J. K. Clegg, J. R. Nitschke, Angew. Chem., Int. Ed. 50 (2011) 3479-3483

[12] T. R. Cook, V. Vajpayee, M. H. Lee, P. J. Stang, K. W. Chi, Acc. Chem. Res. 46 (2013) 2464-2474.

[13] J. Y. Ryu, Y. J. Park, H. R. Park, M. L. Saha, P. J. Stang, J. Lee, J. Am. Chem. Soc. 137 (2015) 13018-13023.

[14] C. R. K. Glasson, G. V. Meehan, M. Davies, C. A. Motti, J. K. Clegg, L. F. Lindoy, Inorg. Chem. 54 (2015) 6986-6992.

[15] M. Newell, J. D. Ingram, T. L. Easun, S. J. Vickers, H. Adams, M. D. Ward, J. A. Thomas, Inorg. Chem. 45 (2006) 821-827.

[16] J. E. Kim, J. A. Bogart, P. J. Carroll, E. J Schelter,. Inorg. Chem. 55 (2016) 775-784.

[17] W.-G. Jia, Y.-F. Han, Y.-J. Lin, L.-H. Weng, G.-X. Jin, Organometallics 28 (2009) 3459-3464.

[18] S. Shanmugaraju, A. K. Bar, S. A. Joshi, Y. P. Patil, P. S. Mukherjee, Organometallics 30 (2011) 1951-1960.

[19] L. Zhang, H. Li, L.-H. Weng, G.-X. Jin, Organometallics 33 (2014) 587-593.

[20] T. Wu, L.-H. Weng, G.-X. Jin, Chem. Commun. 48 (2012) 4435-4437.

[21] K. Sumida, D. L. Rogow, J. A. Mason, T. M. McDonald, E. D. Bloch, Z. R. Herm, T. H. Bae, Long, J. R. Chem. Rev. 112 (2012) 724-781.

[22] Y.-R. Zheng, W.-J. Lan, M. Wang, T. R. Cook, P. J. Stang, J. Am. Chem. Soc. 133 (2011) 1704517055.

[23] N. Ousaka, J. K. Clegg, J. R. Nitschke, Angew. Chem., Int. Ed. 51 (2012) 1464-1468. 


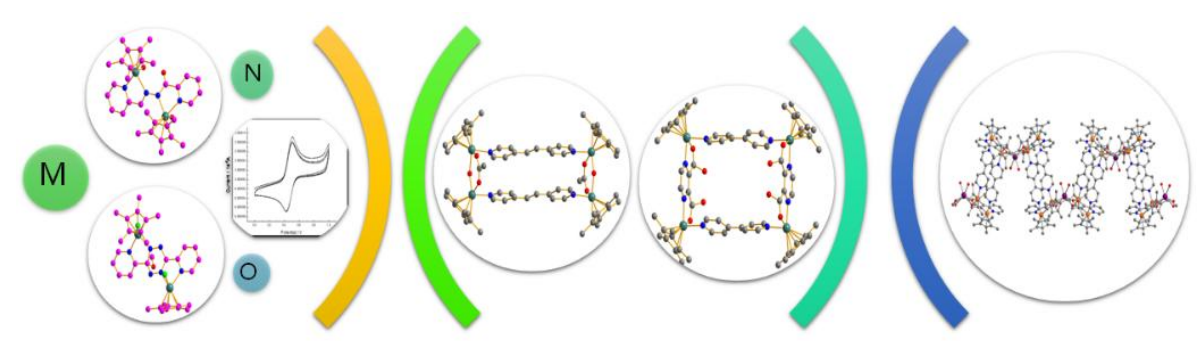

Half-sandwich rhodium and iridium complexes were prepared and their electrochemical properties were studied. A flexible macrocycle substrate led to the existence of a 1D zigzag chain coordination polymer. 